\title{
Land Administration In Kenya: The Case For Leading And Managing Change.
}

\author{
Oloo, Martin Opondo ${ }^{1}$, Dr. Percy Opio ${ }^{2}$, Dr. Walter J. Ongeti ${ }^{3}$ \\ ${ }^{1}$ Scholar, Pan Africa Christian University \\ ${ }^{2,3}$ Lecturer, Pan Africa Christian University \\ DOI: 10.29322/IJSRP.11.05.2021.p11313 \\ http://dx.doi.org/10.29322/IJSRP.11.05.2021.p11313
}

\begin{abstract}
The state of Land administration and management in Kenya has, despite numerous reform efforts, remained fractured and uncoordinated over time. With the adoption of the National Land Policy in 2009, the Constitution of Kenya 2010 and the creation of the National Land Commission (NLC), Land administration and management straddles across two institutions i.e., the Ministry of Lands and Physical Planning, which is created under the Executive Order 2018, and the independent constitution commission, National Land Commission. The land administration functions straddles between the two entities with a performance that is less than satisfactory. Over the years, task forces and commissions have been set up to address the need for security tenure, protection and enforcement of land rights. Most often the solutions proffered have been bureaucratic, administrative and in some cases legal. It is, however, our proposition that strategic leadership through leading and managing change, can play a key role in improving performance of the land administration and management function. The study sought to investigate the influence of leading and managing change on the performance of land administration function in Kenya. The study used both qualitative and quantitative research methods. The target population was 2880 staff who work on land administration and sampled customers who access their services. The Slovin's Formula was used to estimate the sample size. The sample of 351, was arrived at through a stratified random sampling method. In addition, the research employed document analysis at the respective headquarters of the National Land Commission and the Ministry of Lands and Physical Planning. Inferential and descriptive statistics were used to analyse quantitative data with the help of Statistical Package for Social Sciences (SPSS version 22). Descriptive statistics included frequency distribution, mean (the measure of central tendency), standard deviation (the measure of dispersion) and percentages. Besides, inferential statistics include regression analysis and Pearson correlation analysis. Thematic content analysis will be used for qualitative analysis and presented in a narrative form. The study established that leading and managing change has positive and a statistically significant effect on the performance of the Land Administration and management function in Kenya $\left(\beta_{1}=0.468\right.$; $p$-value $\left.=0.000\right)$. The study recommends that the top management in the two organizations should formulate and implement programmes aimed at motivating, rewarding innovativeness and creativity among the employees. In addition, the study recommends that both the Ministry and the NLC should make an effort of increasing the budget for staff training. This will equip the employees with the needed skills to carry out their duties hence improving service delivery.
\end{abstract}

Keywords: Leading Change, Managing Change, Land Administration, Performance

\section{Introduction}

Leaders are central in steering change processes and systems that result in organisational achievement. Leadership is the process of influencing, directing and communicating the activities of an organization to accomplish goals (Touba, Abdulrab \& Ameen, 2015). The organisational leader has to focus on the entire organisational operating activities while monitoring internal \& external changes which affect the organisation (Witts, 2016). Organisations perform poorly where leadership suffers from the inability to convince its staff to follow its vision; the failure to counter or recognise threats; inability to manage resistance to change; and misjudging their capability to control the external environment (Serfontein, 2010). As a result, most of the proposed changes meant to improve efficiency in the Ministry of Land and Physical Planning, face resistance from employees. Muthaura (2014) observed that resistance to change was one of the leading challenges in strategy implementation at the Ministry of Lands and Physical Planning. Leading and managing change is the fundamental element in the operations and policing of organization especially when it focuses on employees and managers.

Studies on leading and managing change are limited in Kenya, where they are available they are conducted in different sectors in both public and private institutions. For instance, Mutungi, Minja and Njoroge (2019) examined the role of change leadership on the transformation of the Kenya Police Service; and Mwangi and Lubasi (2017) studied the relationship between change leadership and employees' commitment in African Development Bank in Kenya. However, these studies were conducted in the Kenya Police Service

This publication is licensed under Creative Commons Attribution CC BY.

http://dx.doi.org/10.29322/IJSRP.11.05.2021.p11313

WWW.ijsrp.org 
and African Development Bank, whose services and mission differ considerably from the Ministry of Land and the National Land Commission as they implement the land administration functions in their respective institutions. In addition, Kenya Police Service and African Development Bank and the Ministry of Lands and Physical Planning as well as the national Land Commission have different functions and structures. As a matter of fact, they are governed by different regulatory frameworks.

According to African Women and Child (2018) reports from the various government commissions suggest that on a general scale, there has been a systematic breakdown in land administration and land delivery procedures throughout Kenya over time. Structures are overcentralized at the Ministry of Lands and key functions over-concentrated at the National level. They further add that the existing land administration and land rights delivery systems are bureaucratic, expensive in terms of transaction costs, undemocratic and prone to abuse, resulting into inordinate delays in the administration of land. In their view, this has made the ordinary Kenyan unable to access the relevant information necessary in land transactions and subsequently land ownership. This study sought to investigate the influence of leading and managing change on the performance of land administration function in Kenya.

The study aimed at testing the following null hypotheses:

Ho1: Leading and managing change has no significant influence on the performance of the land administration function.

\section{Leading and Managing Change}

For employees and managers of corporations, leading and managing change is critical because it is the fundamental element in the operations and policing of their companies (Witts, 2016). The ability to lead is not just an expectation for leaders and managers, rather, it is also necessary for effectiveness and efficiency in organisational leadership. According to Touba, Abdulrab and Ameen (2015), leaders and managers require ability to give guidance and intensification of the awareness towards the ever-dynamic responsibilities and roles encountered in the workplace setting (Serfontein, 2010). Jalagat (2017) indicates that leading and managing people is critical in organizations. Change management is essential in helping employees to cope with the never-ending organisational changes. For staff and employees, the change brings about skills improvement, attitudes abilities \& the knowledge in being more productive in their fields. Jalagat (2017) recommends that organizations should give serious consideration to leading and managing people and general organisational change for them to stay competitive and relevant. Abbas and Asghar (2010) evaluated the role of leadership in organizational change in Sweden. The study used a systematic review of literature and found that 70 per cent of organisational changes fail to achieve their goals. As leadership has a central role in evolution and cultivating an organization, the process of organizational change demands a very effective and highly competent leadership that is well capable to perceive the most desirable shape of an organization and address the issue of organizational change in most appropriate way.

\section{Conceptual Framework}

A conceptual framework is a diagrammatic representation showing the hypothesised associations among crucial factors, variables, and concepts. Figure 1 shows the hypothesised associations between leading and managing change and performance of land administration function. The independent variable is leading and managing change and the dependent variable is performance of land administration function.

\section{Dependent variable}

\section{Independent variable}

Leading and managing change

- Organizational structure

- Adoption of information technology

- Innovation

\section{Figure 1: Conceptual Framework}

Performance of Land Administration Function

- Reduced cost (Cost)

- Shorter cycle time (Time)

- Higher reliance on LA processes (Society)

- Higher customer satisfaction (Customer)

- Continuous improvement (Technological innovation)

- Improved quality of lodged requests (Quality) 


\section{Research Methodology}

The research study utilised the pragmatic approach. It employed both quantitative and qualitative methods of research. In addition, the study deployed cross-sectional study design and mixed methods research. All the staff as well as customers visiting the offices in the Ministry of Lands and National Land Commission in each of the 47 Counties (987 per day were the target population. According to the National Land Commission, an average of 21 individuals visit land offices per day. Besides, the National Land Commission has 462 staff distributed in 11 departments. The Ministry of Lands and Physical Planning has 1431 staff distributed in five directorates: Directorate of land, Directorate of Survey, and Directorate of Physical Planning, Land Registration, and Land Adjudication and Settlement. The target population was therefore, 2880.

This study used a Slovin's Formula to estimate the sample size. The random sample formula was used due to its consideration of the target population.

$$
n=\frac{N}{1+N e^{2}}=\frac{2880}{1+2880 * 0.05^{2}}=351
$$

Where: $\mathrm{n}=$ number of samples (sample size); $\mathrm{N}=$ total population (which in this case is 2880 ); $\mathrm{e}=$ margin of error at $95 \%$ confidence level (0.05)

The study sampled 10 percent of the 47 counties. The selection of $10 \%$ is supported by Mugenda and Mugenda (2003) and Lavrakas (2008) argument that $10 \%$ of the population is an appropriate sample size and can be used in making conclusions about a population. The study will use purposive sampling to select 5 Counties servicing the highest number of clients per day in land administration functions. These counties include Nairobi County, Mombasa County, Kiambu County, Machakos County and Kajiado County. The study utilized the stratified random sampling in selecting a sample of 351. The strata comprised of various departments in the Ministry of lands and planning, National Land Commission and Customers (21 per county). This study made use of both primary data and secondary data. Interview guides and semi-structured questionnaires were used to generate primary data. On the other hand, various reports available in the Commission and the Ministry of Lands and Physical Planning will be the source of secondary data. A pilot test was conducted in the Ministry of Lands and Physical Planning and the Commission in the County Government of Kiambu.

Quantitative data was generated from the closed-ended questions while qualitative data from open-ended questions and key informant interviews. Thematic analysis was used to analyse qualitative data and presentation of results were in a narrative form. Inferential and descriptive statistics was employed to analyse quantitative data with the help of Statistical Package for Social Sciences (SPSS version 22). Descriptive statistics included frequency distribution, mean, standard deviation and percentages. Inferential statistics in this study included regression analysis and Pearson correlation analysis. The regression model for testing the hypotheses was as follows:

$$
Y=\beta_{0}+\beta_{1} X_{1}+\varepsilon
$$

Whereby; $Y=$ Performance of land administration function in Kenya; $\beta_{0}=$ Constant; $\beta_{1}=$ Coefficients; $X_{1}=$ Leading and managing change; $\varepsilon=$ Error term

\section{Research Findings and Discussions}

From the 351 questionnaires which were distributed, 286 were duly filled and returned. The drop-off and pick-up-later method yielded a high response rate of $81.5 \%$. According to Orodho (2003), response rate is the ratio of the interviewed respondents to the sample size intended to be covered by the study. According to Nulty (2011), a response rate of 75 per cent is adequate for analysis, for making conclusions and making inferences about a population. This implies that the response rate of $81.5 \%$ was adequate for analysis, drawing conclusions and reporting.

\section{Descriptive Statistics}

\section{Performance of the Land Administration Function}

The National Land Commission and the Ministry of Lands and Physical Planning employees, as well as customers visiting the offices were requested to indicate their level of agreement on various statements on the performance of the Land Administration Function. The results were as presented in Table 1. As shown by a mean of 3.206 (std. $d v=0.106$ ) the participants were neutral on the statement indicating that the land use policy and regulations are understandable. From the findings, the respondents were neutral on the statement indicating that the process of change of land use is simple. This is shown by a mean of 2.899 (std. $\mathrm{dv}=0.099$ ). As shown by a mean of 3.322 (std. $\mathrm{dv}=0.054$ ) the participants were neutral on the statement stating that the NLC officials demonstrate empathy for LA Customers. Further as shown by a mean of 3.344 (std. $d v=0.086)$ the participants were also neutral on the statement indicating that the Ministry officials offer and honour their assurances to LA service customers. From the results, the respondents were neutral on the This publication is licensed under Creative Commons Attribution CC BY. 
statement indicating that customers are satisfied with responsiveness in (Land Administration) LA service delivery. This is shown by a mean of 3.227 (std. $d v=0.026$ ). In addition, with a mean of 3.255 (std. $d v=0.106)$, the participants were also neutral on the statement indicating that the Ministry officials demonstrate empathy for LA Customers.

However, as shown by a mean of 3.374 (std. $\mathrm{dv}=0.003$ ) the respondents were also neutral on the statement indicating that the NLC officials offer and honour their assurances to LA service customers. Kalantari (2017) argues that service delivery to customers is improved through employee competency in handling customers, quality assurance and adoption of client first slogan. With a mean of 3.605 ( $\mathrm{std}$. $\mathrm{dv}=1.016$ ), the participants also agreed that the Ministry officials are polite to customers. As shown by a mean of 3.636 (std. $\mathrm{dv}=0.999$ ) the participants agreed that the NLC officials are polite to customers. In addition, the respondents agreed that customers have ease of access to the NLC officials. This is shown by a mean of 3.504 (std. $d v=0.207$ ). In addition, with a mean of 3.577 (std. dv $=0.026$ ), the participants also agreed that the Ministry officials communicate information clearly, honestly and promptly to their clients. As shown by a mean of 3.580 (std. dv = 0.987) the participants agreed that the NLC officials communicate information clearly, honestly, and promptly to their clients. However, as shown by a mean of 3.339 (std. $\mathrm{dv}=1.124$ ) the respondents were neutral on the statement indicating that process backflows in the Ministry are low indicating quality work.

With a mean of 3.525 (std. $\mathrm{dv}=0.961$ ), the participants also agreed that delivery time in the NLC is low. Further, as shown by a mean of 3.525 (std. $d v=0.994)$ the participants agreed that delivery time in the Ministry is low. From the findings, the respondents agreed that the waiting time in service delivery is low. This is shown by a mean of 3.504 (std. dv = 1.075). However, as shown by a mean of 3.434 ( std. $\mathrm{dv}=1.070$ ) the respondents were also neutral on the statement indicating that Returned jobs for corrections are low. Further, the respondents were also neutral on the statement indicating that process backflows in the NLC are low indicating quality work. This is indicated by a mean of $3.311(\mathrm{std} . \mathrm{dv}=0.983)$. As shown by the results, the respondents agreed that the NLC staff are skilled in technology \& innovation. This is shown by a mean of 3.549 (std. dv =1.061). With a mean of 3.497 (std. dv = 1.025), the participants were neutral on the statement indicating that the Ministry staff are skilled in technology \& innovation. As shown by a mean of 3.479 (std. $\mathrm{dv}=1.001$ ) the respondents were also neutral on the statement indicating that the NLC has adopted information technology for data capture, processing and management, access, and dissemination. Further, the respondents were also neutral on the statement indicating that the Ministry has adopted information technology for data capture, processing and management, access, and dissemination. This is indicated by a mean of 3.483 (std. $\mathrm{dv}=1.039$ ). Nevertheless, as shown by a mean of $2.434(\mathrm{std}$. dv = 1.009) the participants disagreed with the statement indicating that there is adequate funding for staff training.

\section{Table 1: Performance of the Land Administration Function}

\begin{tabular}{|c|c|c|}
\hline & Mean & $\begin{array}{l}\text { Std. } \\
\text { Deviation }\end{array}$ \\
\hline The land use policy and regulations are understandable & 3.206 & 0.106 \\
\hline The process of change of land use is simple & 2.899 & 0.099 \\
\hline Customers are satisfied with responsiveness in (Land Administration) LA service delivery & 3.227 & 0.026 \\
\hline The Ministry officials demonstrate empathy for LA Customers & 3.255 & 0.106 \\
\hline The NLC officials demonstrate empathy for LA Customers & 3.322 & 0.054 \\
\hline The Ministry officials offer and honour their assurances to LA service customers. & 3.344 & 0.086 \\
\hline The NLC officials offer and honour their assurances to LA service customers. & 3.374 & 0.003 \\
\hline Customers have ease of access to the NLC officials & 3.504 & 0.207 \\
\hline The Ministry officials are polite to customers & 3.605 & 1.016 \\
\hline The NLC officials are polite to customers & 3.636 & 0.999 \\
\hline The Ministry officials communicate information clearly, honestly and promptly to their clients. & 3.577 & 0.026 \\
\hline The NLC officials communicate information clearly, honestly and promptly to their clients. & 3.580 & 0.987 \\
\hline Process backflows in the Ministry are low indicating quality work & 3.339 & 1.124 \\
\hline Process backflows in the NLC are low indicating quality work & 3.311 & 0.983 \\
\hline Returned jobs for corrections are low & 3.434 & 1.070 \\
\hline Delivery time in the Ministry is low & 3.525 & 0.994 \\
\hline Delivery time in the NLC is low & 3.525 & 0.961 \\
\hline The waiting time in service delivery is low & 3.504 & 1.075 \\
\hline $\begin{array}{l}\text { The Ministry has adopted information technology for data capture, processing and management, acces } \\
\text { dissemination }\end{array}$ & and 3.483 & 1.039 \\
\hline $\begin{array}{l}\text { The NLC has adopted information technology for data capture, processing and management, acces } \\
\text { dissemination }\end{array}$ & and 3.479 & 1.001 \\
\hline There is adequate funding for staff training & 2.434 & 1.009 \\
\hline The Ministry staff are skilled in technology \& innovation & 3.497 & 1.025 \\
\hline The NLC staff are skilled in technology \& innovation & 3.549 & 1.061 \\
\hline
\end{tabular}

This publication is licensed under Creative Commons Attribution CC BY.

http://dx.doi.org/10.29322/IJSRP.11.05.2021.p11313

WwW.ijsrp.org 


\section{Leading and Managing Change}

The National Land Commission and the Ministry of Lands and Physical Planning employees as well as customers visiting the offices were requested to indicate their level of agreement on various statements relating to leading and managing change and the performance of the Land Administration Function. The results are as shown in Table 2. Findings showed that the respondents were neutral on the statement indicating that there are frequent changes in the structure of the two entities, that is the Ministry of Land and National Land commission. This is shown by a mean of 3.416 (std. $d v=0.032$ ). In addition, with a mean of 3.392 (std. $\mathrm{dv}=0.002$ ), the participants were also neutral on the statement indicating that there are frequent changes in the structure of the NLC. As shown by a mean of 3.385 (std. $d v=0.005)$ the participants were neutral on the statement stating that task allocation in the Ministry is fair. Further as shown by a mean of 3.329 (std. $\mathrm{dv}=0.035$ ) the respondents were also neutral on the statement indicating that Task allocation in the NLC is fair. As shown by a mean of 2.878 (std. $d v=0.282$ ) the participants were neutral on the statement stating that there are no bureaucracies in the organization.

From the results, the participants agreed that there is easy coordination and supervision in the NLC. This is shown by a mean of 3.559 (std. $d v=0.179)$. As shown by a mean of $3.448(s t d . d v=0.041)$ the respondents were neutral on the statement indicating that NLC has adopted information technology in human resource management. Further, a mean of 3.437 (std. dv $=0.057$ ) the participants were neutral on the statement stating that the Ministry has adopted information technology in the finance department. As shown by a mean of 3.371 (std. $\mathrm{dv}=0.109$ ), the participants were neutral on the statement indicating that there is easy coordination and supervision in the Ministry NLC. In addition, as shown by a mean of 3.385 (std. $\mathrm{dv}=0.089)$ the participants were neutral on the statement that that the Ministry has adopted information technology in human resource management.

With a mean of 3.58 (std. $d v=1.069$ ) the participants agreed that there is knowledge sharing in the NLC. However, as by a mean of 3.42 (std. $\mathrm{dv}=1.136$ ) they were neutral on the statement indicating that there is knowledge sharing in the Ministry. In addition, with a mean of 3.350 (std. $d v=0.135$ ), the participants were also neutral on the statement indicating that the NLC has adopted information technology in the finance department. As shown by a mean of 3.297 (std. dv = 1.019) the participants were neutral on the statement stating that information technology has been adopted in service delivery to the public. However, as shown by a mean of 2.49 (std. $\mathrm{dv}=$ 1.101) the participants disagreed with the statement stating that the Ministry encourages creativity among staff. In addition, as shown by a mean of $2.23($ std. $\mathrm{dv}=1.134)$ the respondents disagreed with the statement indicating that the NLC encourages creativity among staff.

Table 2: Aspects of Leading and Managing Change

\begin{tabular}{lll}
\hline & Mean & Std. Deviation \\
\hline There are frequent changes in the structure of the Ministry & 3.416 & 0.032 \\
There are frequent changes in the structure of the NLC & 3.392 & 0.002 \\
Task allocation in the Ministry is fair & 3.385 & 0.005 \\
Task allocation in the NLC is fair & 3.329 & 0.035 \\
There are no bureaucracies in the organization & 2.878 & 0.282 \\
There is easy coordination and supervision in the Ministry & 3.371 & 0.109 \\
There is easy coordination and supervision in the NLC & 3.559 & 0.179 \\
The Ministry has adopted information technology in human resource management & 3.448 & 0.089 \\
The NLC has adopted information technology in human resource management & 3.437 & 0.041 \\
The Ministry has adopted information technology in the finance department & 3.350 & 0.057 \\
The NLC has adopted information technology in the finance department & 3.297 & 1.019 \\
Information technology has been adopted in service delivery to the public & 2.23 & 1.134 \\
The NLC encourages creativity among staff & 2.49 & 1.101 \\
The Ministry encourages creativity among staff & 3.58 & 1.069 \\
There is knowledge sharing in the NLC & 3.42 & 1.136 \\
There is knowledge sharing in the Ministry & &
\end{tabular}

\section{Correlation Analysis}

The Pearson correlation analysis was used during this study to determine the relationship between dependent (the performance of the land administration function) and the independent variable (leading and managing change). The results revealed that leading and managing change has a positive and significant influence on the performance of the Land Administration Function ( $r=0.498$, $p$ value $=0.000)$. The association was also significant since the $\mathrm{p}$ value $(0.000)$ was less than 0.05 which is the significant level.

\section{Table 3: Correlations Coefficients}




\begin{tabular}{|c|c|c|c|}
\hline & & $\begin{array}{l}\text { Performance of the } \\
\text { Administration Function }\end{array}$ & $\begin{array}{c}\text { LandLeading and Managing } \\
\text { Change }\end{array}$ \\
\hline Performance & LandPearson Correlation & 1 & \\
\hline Administration Function & Sig. (2-tailed) & & \\
\hline & $\mathrm{N}$ & 286 & \\
\hline Leading and Managing Change & Pearson Correlation & .498 & 1 \\
\hline & Sig. (2-tailed) & .000 & \\
\hline & $\mathrm{N}$ & 286 & 286 \\
\hline
\end{tabular}

\section{Regression Analysis}

The r-squared for the relationship between leading and managing change and the performance of the land administration function in Kenya was 0.248 . This shows that leading and managing change can explain $24.8 \%$ of the performance of the land administration function in Kenya. This implies that $75.2 \%$ of the performance of the land administration function in Kenya is accounted for by other factors not considered in the model.

Table 4: Model Summary

\begin{tabular}{lllll}
\hline Model & R & R Square & Adjusted R Square & Std. Error of the Estimate \\
\hline 1 & $.498^{\mathrm{a}}$ & .248 & .245 & .60390 \\
\hline
\end{tabular}

a. Predictors: (Constant), Leading and Managing Change

The F-calculated (93.465) was greater than the F-critical (3.874). In addition, the p-value (0.000) was less than the significance level (0.05). This implies that the model is a good fit for the data and hence can be used to predict the effect of leading and managing change on the performance of the land administration function in Kenya.

Table 7: Analysis of Variance

\begin{tabular}{llllll}
\hline Model & Sum of Squares & df & Mean Square & F & Sig. \\
\hline 1 & Regression & 34.086 & 1 & 34.086 & 93.465 \\
& Residual & 103.574 & 284 & .365 & $.000^{\mathrm{b}}$ \\
& Total & 137.660 & 285 & & \\
\hline
\end{tabular}

a. Dependent Variable: Performance of the Land Administration Function

b. Predictors: (Constant), Leading and Managing Change

The findings, as depicted in Table 8, show that the performance of the land administration function in Kenya will be having an in index of 1.810 when leading and managing change is held constant. In addition, the Beta coefficient was 0.468 for the relationship between leading and managing change and the performance of the land administration function in Kenya. This shows that a unit improvement in leading and managing change would lead to a 0.468 improvement the performance of the land administration function in Kenya. The relationship is significant as the P-value (0.000) was less than the significance level (0.05). Therefore, we can reject the null hypothesis that "Leading and managing change has no significant effect on the performance of the land administration function in Kenya". 
Table 8: Regression Coefficients

\begin{tabular}{|c|c|c|c|c|c|}
\hline \multirow[t]{2}{*}{ Model } & \multicolumn{2}{|c|}{ Unstandardized Coefficients } & Standardized Coefficients & \multirow[t]{2}{*}{$\mathbf{t}$} & \multirow[t]{2}{*}{ Sig. } \\
\hline & $\overline{\mathrm{B}}$ & Std. Error & Beta & & \\
\hline $\begin{array}{ll}1 & \text { (Constant) } \\
& \text { Leading and Managing Chanoe }\end{array}$ & $\begin{array}{c}1.810 \\
468\end{array}$ & $\begin{array}{r}.167 \\
048\end{array}$ & 498 & $\begin{array}{l}10.860 \\
9.668\end{array}$ & $\begin{aligned} .000 \\
000\end{aligned}$ \\
\hline
\end{tabular}

a. Dependent Variable: Performance of the Land Administration Function

\section{Conclusion}

The study concludes that leading and managing change has a positive and a statistically significant effect on the performance of the Land Administration Function in Kenya. The study revealed that that organisational structure, adoption of information technology and innovation influences performance of land administration in Kenya. The findings revealed that both the Ministry of Land and the NLC do not encourage creativity among staff. This study therefore recommends that the top management in both the Ministry of Land and the NLC should formulate and implement programmes aimed at motivating and rewarding innovativeness and creativity among the employees.

\section{References}

Abbas, A. \& Asghar, I. (2010). The Role of Leadership in Organizational Change: Relating the successful Organizational Change with Visionary and Innovative Leadership. Retrieved from http://hig.diva-portal.org/

Olubayo, O. T. (2014). Change Management and its Effects on Organizational Performance of Nigerian Telecoms Industries: Empirical Insight from Airtel Nigeria. International Journal of Humanities Social Sciences and Education, 1(11), 70-179.

Nulty, D.D. (2011). How to Calculate Response Rate.Science Journal, 33(3), 301-314.

African Women and Child (2018). Expert Analysis: Land Administration and Land rights Delivery in Kenya. Retrieved from www.awcfs.org/

Jalagat, C. (2017). Leading and Managing People and Organizational Change: Individual Organizational Benefits and Its Value on Staff Development. Business, Management and Economics Research, 3(8), 146-150.

Jumanne, A. S., \& Njoroge, D. J. (2018). Leadership Change Management and Employee Performance in the Parliamentary Service Commission of Kenya. American Journal of Leadership and Governance, 3(1), 62 - 77.

Kalantari, M. (2017). Developing a Land Administration Index. Washington D.C: The World Bank.

Lavrakas, P.J. (2008) Encyclopedia of survey research methods. Thousand Oaks: Sage Publications, Inc.

Mugenda, O. M. \& Mugenda, A. G. (2003). Research methods: Quantitative and qualitative Approaches. Nairobi: African Centre for Technology Studies.

Muthaura, R.W. (2014). Challenges Facing Strategy Implementation in the Ministry of Lands, Housing and Urban Development in Kenya. Retrieved from http://erepository.uonbi.ac.ke/bitstream/handle/11295/76256

Mutungi, M., Minja, D. \& Njoroge, G. (2019). The role of change leadership on the transformation of the Kenya Police Service. International Journal of Scientific and Research Publications, 9, 85-96.

Mwangi, J.K. \& Lubasi, R.A. (2017). Change Leadership and Employees' Commitment: A Case of African Development Bank in Kenya. The International Journal of Business Management, 5(2), 32-43.

Nyaungwa, C., Linganiso, X. \& Karodia, A.M. (2015). Assessing the Impact of Change Management on the Performance of Zimra Region in Zimbabwe. Journal of Business and Management Review, 4(6), 76-121.

Orodho, A. J. (2007). Techniques of Writing Research Proposal and Reports. Nairobi: HP Enterprises.

Oreg, S., \& Berson, Y. (2019). Leaders' impact on organizational change: Bridging theoretical and methodological chasms. The Academy of Management Annals, 13(1), 272-307

Serfontein, J.J. (2010). The impact of strategic leadership on the operational strategy and performance of business organizations in South Africa. Retrieved from http://citeseerx.ist.psu.edu/viewdoc/

Touba, D.S.M., Abdulrab, M. \& Ameen, A.A. (2015). The Effect of Strategic Thinking on Organizational Performance in Oil and Gas Industry in Libya. Journal of Business and Change Management, 12, 54-78.

Witts, J.O. (2016). The Role of Strategic Leadership in Banking Profitability. Retrieved from http://scholarworks.waldenu.edu/dissertations? 